\title{
Dual effect of a Tn917 insertion into the Bacillus subtilis sacX gene
}

\author{
Dominique Le CoQ, ${ }^{*}$ StÉPhane Aymerich and Michel Steingetz
}

Laboratoire de Génétique des Microorganismes, Institut National Agronomique, CBAI, F-78850 Thiverval-Grignon, France

(Received 31 May 1990; revised 23 July 1990; accepted 19 September 1990)

\begin{abstract}
The most common effect of transposon insertion is the inactivation of genes. However, in some cases, transposons can activate in cis the expression of genes in the neighbourhood of their integration site. We previously described an insertion of the transposon Tn917 into the Bacillus subtilis sacXY locus. sacX and sacY encode respectively a negative and a positive regulator involved in induction by sucrose of the exoenzyme levansucrase. Data in this paper show that the Tn917 insertion had two effects: it inactivated sacX $X$ and it increased the transcription of $\operatorname{sac} Y$. The latter effect involved one or several elements internal to the transposon.
\end{abstract}

\section{Introduction}

Transposons are mobile genetic elements whose insertion into genomes contributes to genetic variability (Berg \& Howe, 1989). The most common effect of transposon insertion is the inactivation of the target gene. This can be due to interruption of the coding sequence, to genetic rearrangements (Reif \& Saedler, 1975), or to negative polar effects when a transposon carrying a transcription terminator inserts between the promoter of a gene and its coding sequence (Galas \& Chandler, 1989). Transposon insertions can also occasionally activate in cis the expression of silent or weakly expressed genes. The latter effect can be observed for example if an outwarddirected promoter present within the transposon promotes transcription of external sequences (Ciampi et al., 1982).

Youngman and coworkers have developed the Streptococcus faecalis transposon $\operatorname{Tn} 917$ as a tool for studying the genetics of Bacillus subtilis and other Gram-positive bacteria (Perkins \& Youngman, 1984; Youngman et al., 1985; Youngman, 1987). This transposon belongs to the Tn 3 family. Its general organization, deduced from its nucleotide sequence (Shaw \& Clewell, 1985), is presented in Fig. 1. We previously characterized a $\operatorname{Tn} 917$ insertion into the B. subtilis sac $X Y$ locus (formerly sacS) (Aymerich \& Steinmetz, 1987), which is involved in the induction by sucrose of the $s a c B$-encoded exoenzyme levansucrase (Lepesant et al., 1976). This Tn917 insertion led to a constitutive levansucrase phenotype, which was therefore interpreted as being due to the inactivation of a gene (subsequently designated $\operatorname{sac} X$ ) encoding a negative regulator. Additional experiments showed that a second gene (designated $\operatorname{sac} Y$ ), downstream of $\operatorname{sacX}$ (Fig. 1), encoded a positive regulator of levansucrase induction

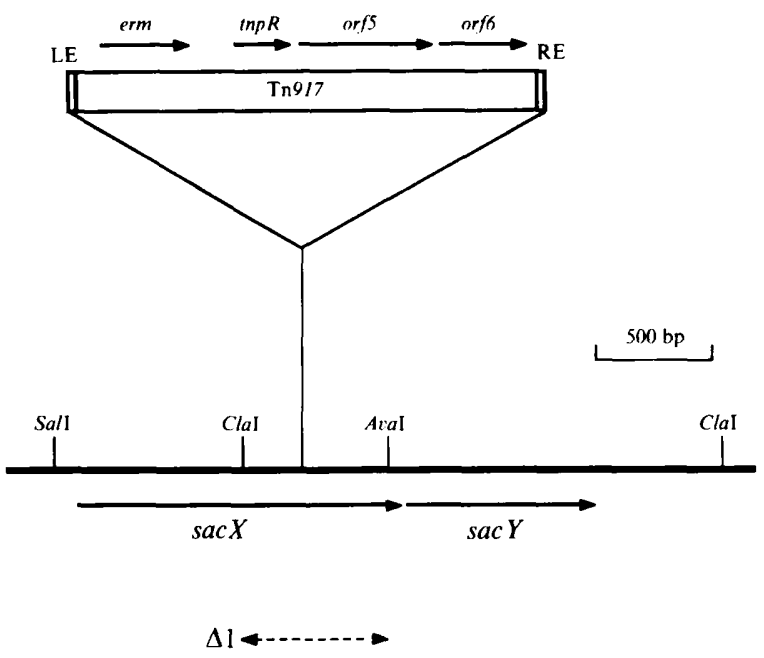

Fig. 1. Structure of the $\operatorname{sac} X Y$ locus and of $\operatorname{sac} X$ mutations. The restriction map was deduced from the DNA sequence (Zukowski et al., $1988,1990)$. The insertion site of $\operatorname{Tn} 917$. into sac $X$ was determined from the restriction map of plasmids pSL4 and pSL9 (Amyerich \& Steinmetz, 1987). The $\operatorname{sac} X \Delta I$ deletion $(\Delta 1)$ is an in-frame deletion within sacX extending from the ClaI site to the Aval site (Crutz et al., 1990). $\operatorname{Tn} 917$, which is 5257 bp long (Shaw \& Clewell, 1985), is not drawn to scale. It contains four open reading frames of more than fifty codons, oriented in the same direction (arrows). LE, left-hand end; RE, right-hand end; erm, erythromycin-resistance gene; $t m p R$, gene encoding resolvase; orf5 and orf6, open reading frames probably encoding the transposase (Perkins \& Youngman, 1984; Shaw \& Clewell, 1985; Murphy, 1989). 
(Aymerich \& Steinmetz, 1987; Steinmetz et al., 1988) and suggested that $\mathrm{SacX}$ was an inhibitor of SacY in the absence of sucrose (Crutz et al., 1990). Since there is no obvious transcription terminator between sacX and sac $Y$ (Zukowski et al., 1988, 1990), sac $Y$ could be transcribed, at least in part, from the $\operatorname{sac} X$ promoter. This prompted us to compare the phenotype of the sac $X:$ : Tn 917 mutant with that of mutants carrying other alterations of $\operatorname{sacX}$.

We present here evidence that the sacX::Tn917 insertion not only inactivated the gene for the SacX negative regulator, but also stimulated the expression of the gene coding for the SacY positive regulator. This observation shows that, as in the case of transposons of Gram-negative bacteria (Ciampi et al., 1982), the phenotype of some Tn917-derived mutants may not simply be the result of insertional inactivation of the target gene. We also describe procedures that allow the other activities of inserted transposons to be recognized.

\section{Methods}

Bacterial strains. Escherichia coli strain TGl (supE hsd $\Delta 5$ thi $\Delta($ lacproAB) $\mathrm{F}^{\prime}$ traD36 proAB ${ }^{+}$lac $1^{q}$ lacZ $\left.\triangle M 15\right]$ was used as a host for the construction of plasmids. Bacillus subtilis strains are listed in Table 1. QB1072 and GM124 have been described previously (Aymerich \& Steinmetz, 1987); GM275a is a GM124 derivative in which the lac $Z$ gene present within the $T n 917$ variant inserted into $s a c X$ was deleted in two steps as described in Fig. 2. GM276 and GM729 are derivatives of GM275a and QB1072, respectively, carrying the $\operatorname{sacB} B^{\prime}-l a c Z$ fusion (Aymerich et al., 1986). This fusion was introduced into the chromosome of these strains using plasmid pLG331 (Crutz et al., 1990). GM687, GM688, GM689, GM690 and GM706 are derivatives of

Table 1. Bacterial strains

\begin{tabular}{|c|c|c|}
\hline Strain & Genotype* & Origin $\dagger$ \\
\hline QB1072 & Wild-type & 1 \\
\hline GM124 & sacX::Tn917-lac & 1 \\
\hline GM275 & sacX: :Tn917-lac' : :'pIC11 & 2 \\
\hline GM275a & $\operatorname{sacX}:: \operatorname{Tn} 917$ & 2 \\
\hline GM276 & $\operatorname{sac} X: \operatorname{Tn} 917, \operatorname{sac} B^{\prime}-' \operatorname{lac} Z$ & 2 \\
\hline GM682 & $\operatorname{sac} X \Delta l$ & 2 \\
\hline GM684 & $\operatorname{sac} Y:: \mathrm{pSL} 170$ & 2 \\
\hline GM685 & sacX $:: \operatorname{Tn} 917, \operatorname{sac} Y:: \mathrm{pSL} 170$ & 2 \\
\hline GM686 & $\operatorname{sac} X \Delta l, \operatorname{sac} Y:: \mathrm{pSL} 170$ & 2 \\
\hline GM687 & 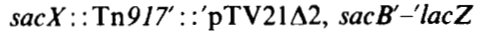 & 2 \\
\hline GM688 & sacX::Tn917::pIC42, sacB'-lacZ & 2 \\
\hline GM689 & sacX::Tn917::pIC47, sacB'-'lacZ & 2 \\
\hline GM690 & sacX::Tn917::pIC48, sacB'-lacZ & 2 \\
\hline GM706 & sacX::Tn917::pIC41, sacB'-'lacZ & 2 \\
\hline GM729 & 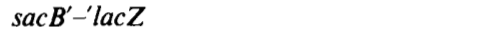 & 2 \\
\hline GM730 & $\operatorname{sac} X \Delta I, \operatorname{sac} B^{\prime}-{ }^{\prime} l a c Z$ & 2 \\
\hline
\end{tabular}

* All the strains carry the sacA321 mutation. The Tn 917 transposon carried by GM275a and derivatives is that carried by pTV8 (Youngman, 1987).

$\uparrow 1$, Aymerich \& Steinmetz (1987); 2, this work.
GM276 transformed with pTV21 2 2, pIC42, pIC47, pIC48 and pIC41, respectively, as shown in Fig. 3. GM682 and GM730 are derivatives of QB1072 and GM729 respectively, in which the sac $X \Delta 1$ deletion was introduced in two steps using pSL132 and pSL85-X $\triangle 1$ as previously described (Crutz et al., 1990). GM684, GM685 and GM686 are derivatives of QB1072, GM275a and GM682, respectively, carrying the plasmid pSL170 inserted into sac $Y$ (Fig. 4).

Plasmids. The following plasmids have been described previously: pLG331, pSL85-X $\Delta 1$ and pSL132 (Crutz et al., 1990); pTV8 and pTV21 $\Delta 2$ (Youngman, 1987). Plasmid constructions and analyses were performed using standard techniques; ligations of incompatible ends were performed after filling extremities with DNA polymerase (Klenow fragment). Plasmid pIC11 (shown linearized at its $\mathrm{ClaI}$ site in Fig. 2) contains a 1825 bp ClaI-PvuII fragment of $l a c Z$, the $P v u I I-$ $B g / I I$ fragment of pTV21 $\triangle 2$ (including the pBR322 origin and the chloramphenicol-resistance gene), and the right-hand end of $\operatorname{Tn} 917$ minus the last 33 nucleotides ( $B g / \mathrm{II}-\mathrm{ClaI}$ fragment). The construction of pTV21 $\Delta 2$ derivatives pIC41 and pIC42 is shown in Fig. 3. Plasmids $\mathrm{pIC} 47$ and $\mathrm{pIC} 48$ were derived from pIC42 as described in the legend of Fig. 3. Plasmid pSL170 was derived from pJM783 (Perego et al., 1988) and pSL150 (Crutz et al., 1990) as described in the legend of Fig. 4.
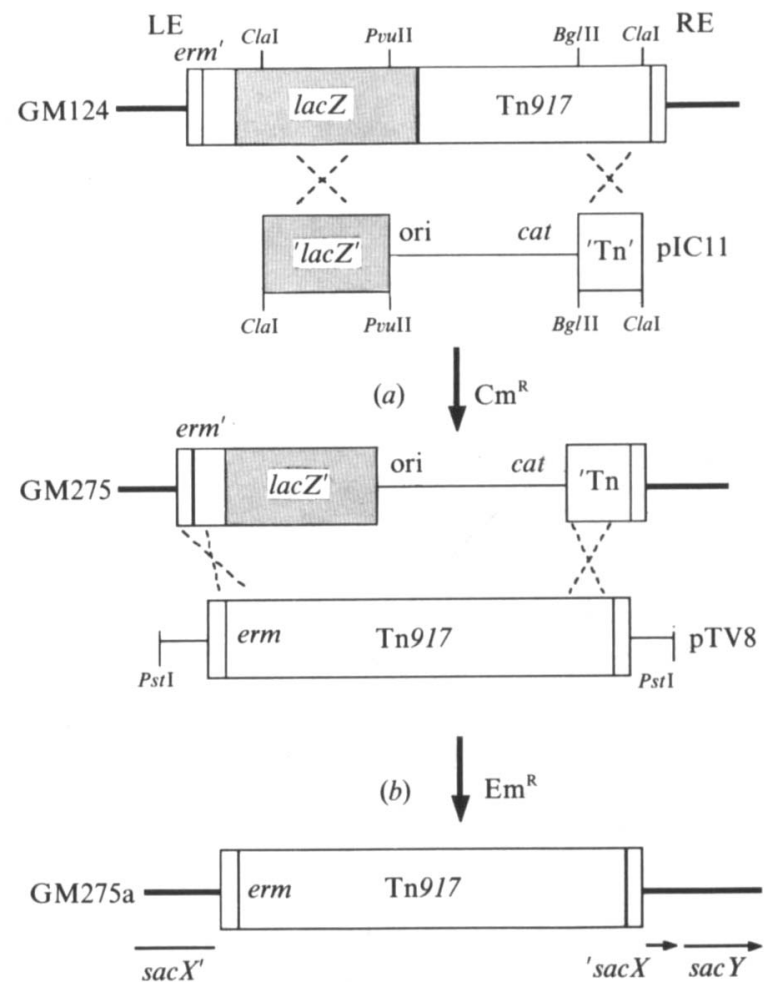

Fig. 2. Construction of strain GM275a. (a) GM124 was transformed by pIC11 linearized by ClaI. Chloramphenicol-resistant $\left(\mathrm{Cm}^{\mathrm{R}}\right)$ transformants (which were erythromycin sensitive) were selected. (b) The resulting strain GM275 was transformed by pTV8 linearized by PstI. Erythromycin-resistant $\left(\mathrm{Em}^{\mathrm{R}}\right)$ transformants were selected. ori, pBR322 origin of replication; cat, chloramphenicol-resistance gene; erm, erythromycin-resistance gene; LE, left-hand end; RE, right-hand end; crosses, cross-over events. Truncated parts of genes or transposon are symbolized by primes ('). 


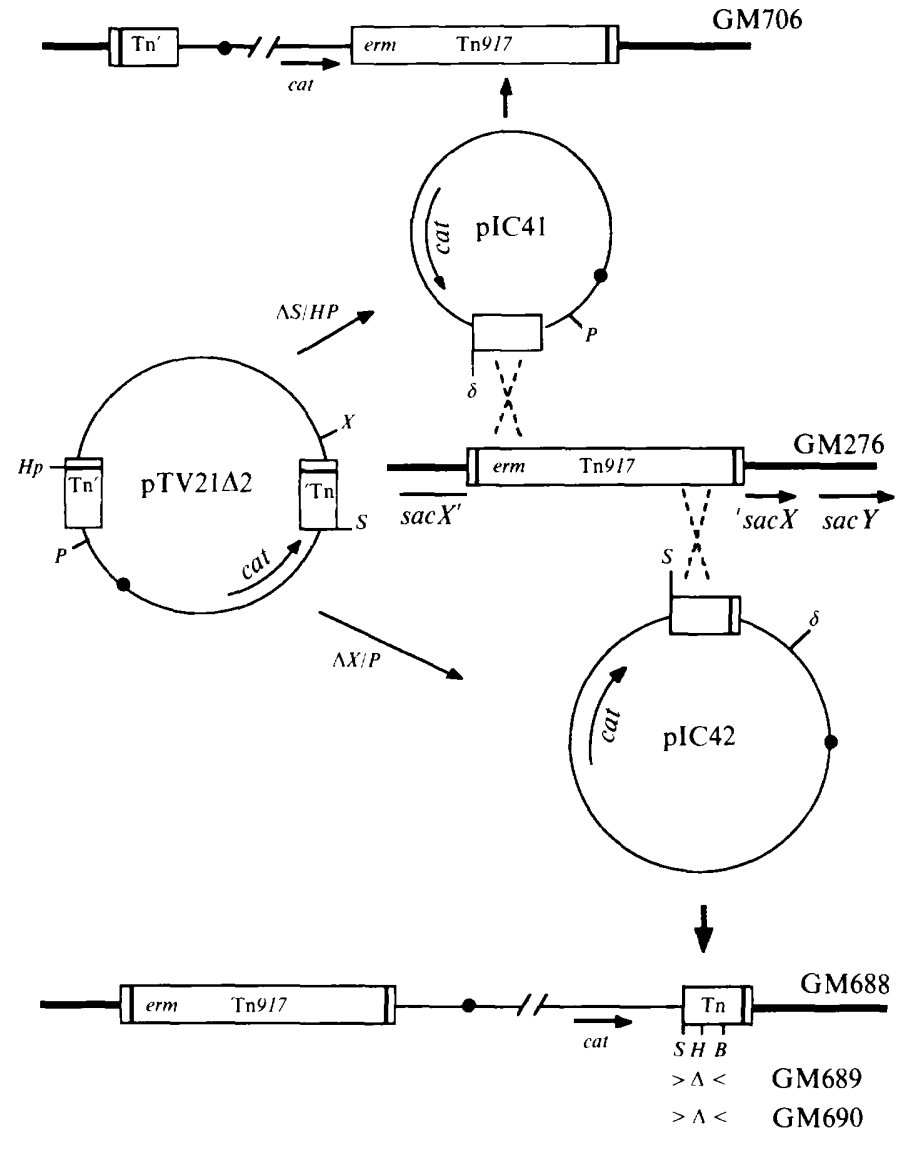

GM276 $\times$ pTV $21 \Delta 2$

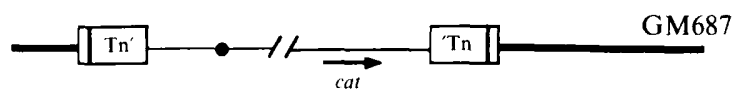

Fig. 3. Construction and insertion of plasmids into the chromosome of GM276. Plasmids pIC41 and pIC42 were derived from $\mathrm{pTV} 21 \Delta 2$ by a $S a l \mathrm{I} / \mathrm{HpaI}(\Delta S / H p)$ and a $X b a \mathrm{I} / P v u I I(\Delta X / P)$ deletion, respectively; the point corresponding to the deletion is indicated in pIC41 and pIC42 by a $\delta$. Integration of these plasmids into the chromosome of GM276 led to GM706 and GM688, respectively. Plasmids pIC47 and pIC48 were derived from pIC42 by a SalI/HindIII and a SalI/BglII deletion, respectively; integration of these plasmids into the chromosome of GM276 led to GM689 and GM690, respectively, similar to GM688, except that they have respectively a $S a l \mathrm{I} / \mathrm{HindIII}$ and a $\mathrm{Sal} / \mathrm{Bg} / \mathrm{III}$ deletion (indicated by $>\Delta<$ ) in the portion of the transposon remaining just upstream of $\operatorname{sac} Y$. The structure of GM687, in which part of the transposon is substituted by pTV21 $\Delta 2$ sequences, is also shown. $B, H, H p, P, S$ and $X$ represent BglII, HindIII, HpaI, PvuII, SalI and $X b a \mathrm{I}$ restriction sites, respectively. The origin of replication of plasmids is represented by a black point. cat, chloramphenicol-resistance gene; erm, erythromycin-resistance gene; crosses, cross-over events; $\mathrm{Tn}^{\prime}$ ' and 'Tn symbolize transposon Tn $9 I 7$ truncated of its right and left part, respectively.
Transformations, media and enzyme assays. E. coli and B. subtilis were transformed using standard protocols as described previously (Crutz $e t$ al., 1990). Transformants were selected on LB solid medium (Miller, 1972) supplemented with appropriate antibiotics. When required, integration of a single plasmid copy into the $B$. subtilis chromosome was screened as previously described (Aymerich et al., 1986). Growth of liquid cultures of $B$. subtilis in CG medium and preparation of enzyme extracts were done as previously described (Aymerich et al., 1986). Assay of $\beta$-galactosidase was performed according to Miller (1972).

\section{Results}

\section{Constitutivity in different sacX mutants}

We looked at the effect of $\operatorname{sac} X:: \operatorname{Tn} 917$ on the expression of the downstream $\operatorname{sac} Y$ gene by comparing the phenotype of two mutants, with isogenic back- grounds, differently affected in sacX. These mutants carried the $\operatorname{sac} B^{\prime}-{ }^{\prime} l a c Z$ fusion, whose expression was previously shown to be regulated in an identical way to that of the sacB gene (Aymerich et al., 1986). The sacX $\Delta I$ mutation is an in-frame deletion within the sac $X$ coding sequence, in which about $46 \%$ of the codons are removed (Fig. 1). This mutation led to a constitutive expression of the $l a c Z$ reporter gene, as previously observed (Crutz et al., 1990). Table 2 shows that the sacX::Tn 917 mutant also expressed the lac $Z$ reporter gene constitutively, but at a much higher level than that observed in the sac $X \Delta I$ mutant. Since SacY is an activator of transcription of $\operatorname{sacB}$, the difference in phenotypes could reflect differences in the expression of $\operatorname{sac} Y$. In order to analyse a possible positive effect of the $\operatorname{Tn} 917$ sequences on $\operatorname{sac} Y$ expression, we constructed strains in which the trans- 

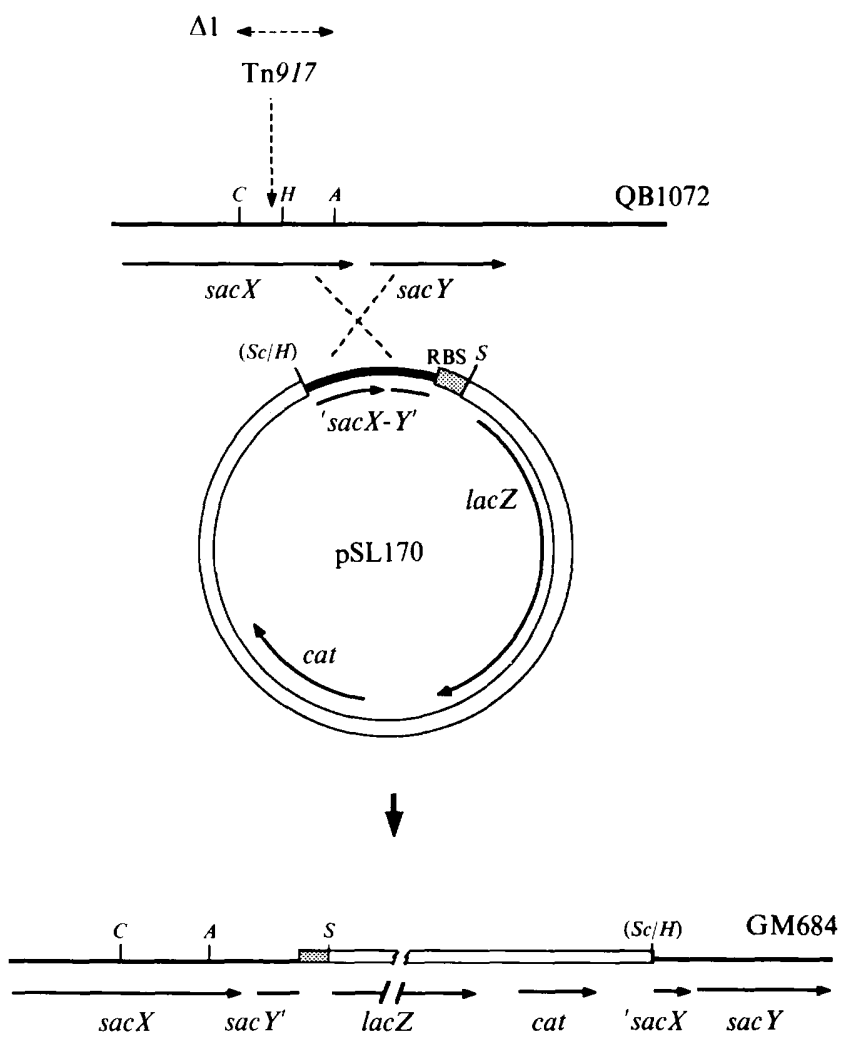

Fig. 4. Structure of plasmid pSL170 and insertion into sacY. The $613 \mathrm{bp} \mathrm{Scal/SalI} \mathrm{fragment} \mathrm{of} \mathrm{pJM783} \mathrm{was} \mathrm{replaced} \mathrm{by} \mathrm{a} 723 \mathrm{bp}$ HincII/SalI fragment from pSL150 carrying the $3^{\prime}$ end of $s a c X$, the $5^{\prime}$ end of sac $Y$ and the spoVG ribosome-binding site (RBS, dotted area). This led to the integrative plasmid $\mathrm{pSL} 170$, which contains a sac $Y^{\prime}-$ lac $Z$ transcriptional fusion. $A, C, H, S$ and $S c$ represent $A v a l, C l a I$, HincII, SalI and ScaI restriction sites, respectively; $(\mathrm{Sc} / \mathrm{H})$ stands for the Scal/Hincll ligation, which destroyed both sites. cat, chloramphenicol-resistance gene; cross, cross-over event. Genes are represented by arrows, indicating their orientation. The positions of the $\operatorname{Tn} 917$ insertion and the $\operatorname{sac} X \Delta l$ deletion are shown.

poson contained a variety of insertions. GM276 ( $\operatorname{sacX}:: \operatorname{Tn} 917)$ was transformed by plasmid pIC42, giving GM688, in which the region immediately upstream of $\operatorname{sac} Y$ consists of a small fragment of $\mathrm{Tn} 917$ from its unique $S a l I$ site to the nearest transposon end; upstream of this SalI site lie plasmid sequences (Fig. 3). As shown in Table 2, the constitutive $\beta$-galactosidase activity was greatly reduced by this insertion. When GM276 was transformed by pTV $21 \Delta 2$, integration of the plasmid occurred through a double recombination event (Youngman, 1987), giving GM687, in which part of the transposon upstream of $S a l l$ was replaced by plasmid sequences (Fig. 3). The level of $\beta$-galactosidase activity in this strain was comparable to that in GM688, i.e. greatly reduced (Table 2). Besides this, GM706, in which most of the transposon just upstream of $\operatorname{sac} Y$ is intact, had a phenotype similar to that of GM276 (Table 2).
Table 2. Expression of the sacB'-'lacZ fusion in GM729 and isogenic sacX mutants

\begin{tabular}{|c|c|c|}
\hline Strain & Relevant genotype* & $\begin{array}{c}\beta \text {-Galactosidase } \\
\text { activity } \dagger\end{array}$ \\
\hline GM729 & Wild-type & $<0.1$ (induced: 11.8 ) \\
\hline GM730 & $\operatorname{sac} X \Delta \mathrm{l}$ & 6.9 \\
\hline GM276 & $\operatorname{sac} X:: \operatorname{Tn} 917$ & $209 \cdot 4$ \\
\hline GM687 & $\operatorname{sac} X:: \operatorname{Tn} 917^{\prime}:: \mathbf{p}^{\prime} T \mathrm{2} 1 \Delta 2$ & $20 \cdot 5$ \\
\hline GM706 & sacX::Tn917::pIC41 & $220 \cdot 7$ \\
\hline GM688 & $\operatorname{sac} X:: \operatorname{Tn} 917:: \mathrm{pIC} 42$ & $26 \cdot 7$ \\
\hline GM689 & sacX::Tn917::pIC47 & $19 \cdot 3$ \\
\hline GM690 & sacX : :Tn917::pIC48 & $15 \cdot 3$ \\
\hline
\end{tabular}

* All these strains carry the $\operatorname{sac} \boldsymbol{B}^{\prime}-' \operatorname{lac} Z$ fusion.

$\dagger$ Expressed in Miller units. These activities correspond to a typical experiment. Similar results were reproducibly obtained in several experiments.

Table 3. Effect of Tn917 on the expression of the sac $Y^{\prime}$-lacZ fusion

\begin{tabular}{llc}
\hline \hline Strain & Relevant genotype & $\begin{array}{c}\beta \text {-Galactosidase } \\
\text { activity* }\end{array}$ \\
\hline QB1072 & Wild-type & $<0.1$ \\
GM684 & sacY'lacZ & 0.5 \\
GM685 & sacY'lacZ, sacX::Tn917 & 3.6 \\
GM686 & sac $Y^{\prime}$-lacZ, sacX $\Delta 1$ & 0.5 \\
\hline \hline
\end{tabular}

* Expressed in Miller units. See footnote $\dagger$ of Table 2.

These results suggested that the region upstream of the SalI site on the transposon had a positive effect on $s a c B$ expression.

The sacX : :Tn917 insertion has a positive effect on sac $Y$ transcription

The phenotypes observed in different $\operatorname{sac} X$ mutants were likely to reflect the levels of the SacY positive regulator. In order to measure directly any activating effect of the sac $X:$ : $\operatorname{Tn} 917$ insertion on sac $Y$ transcription, we constructed a transcriptional fusion of $\operatorname{sac} Y$ and $l a c Z$ and introduced it into the chromosome of different $s a c X$ mutants (Fig. 4). The $\beta$-galactosidase activities of the transformants show that the $\operatorname{sac} X:: \operatorname{Tn} 917$ insertion increased the expression of the lac $Z$ reporter gene (Table 3 ), demonstrating the positive effect of the insertion on sac $Y$ transcription.

Effect of the Tn917 sequences located downstream of the Sall site

The level of $\beta$-galactosidase produced constitutively by strain GM688 ( $\operatorname{sac} X:: \operatorname{Tn} 917::$ pIC42) was significantly higher than that of GM730 ( $\operatorname{sac} X \Delta 1)$. This difference could have been due to a weak residual positive effect of 
the part of $\operatorname{Tn} 917$ remaining just upstream of $s a c Y$ in GM688. Therefore, we created deletions in this region by constructing strains GM689 and GM690, in which the remaining part of $\mathrm{Tn} 917$ was shortened from the SalI site (Fig. 3). The level of $\beta$-galactosidase activity in these strains was reduced as compared to that of GM688, and the reduction correlated with the extent of the deletion (Table 2). This result showed that the $\mathrm{Tn} 917$ region downstream of SalI had a minor, positive effect on expression of $\operatorname{sac} Y$ in the $\operatorname{sac} X:: \operatorname{Tn} 917$ mutant.

\section{Discussion}

Using a $\operatorname{sac} Y^{\prime}-{ }^{\prime} l a c Z$ transcriptional fusion, we showed that the $\operatorname{sac} X:: \operatorname{Tn} 917$ insertion stimulated transcription of the $\operatorname{sac} Y$ gene located downstream of $\operatorname{sac} X$ (Table 3). The increased transcription of $\operatorname{sac} Y$ led to a constitutive expression of $s a c B$ that was much stronger than that observed in a sac $X \Delta 1$ mutant or in an induced wild-type strain (Table 2). This supports the suggestion that SacY is limiting for the induction of $s a c B$ in the wild-type strain (Henner et al., 1987; Crutz et al., 1990).

The question remains as to what is the basis of the effect of Tn917. Relatively little is known about the transcriptional activity of $\operatorname{Tn} 917$ and its effects on the transcription of genes adjacent to the integration site. Shaw \& Clewell (1985) have shown that, in a $S$. faecalis strain carrying the transposon on a plasmid, several $\operatorname{Tn} 917$-specific transcripts are present. Some of these transcripts start from the erm promoter and extend towards the right-hand end of the transposon. The influence of insertions in GM687 ( $\operatorname{sacX}:: \mathrm{Tn}$ $\left.917^{\prime}:: ' \mathrm{pTV} 21 \Delta 2\right)$ and GM688 ( $\left.\operatorname{sac} X:: \operatorname{Tn} 917:: \mathrm{pIC} 42\right)$ on $\beta$-galactosidase activity could be due to the presence of the chloramphenicol-resistance gene (cat) and its terminator between the erm promoter and sacY. As previously shown by Vandeyar et al. (1986), a cat insertion into $\operatorname{Tn} 917$ had a strong polar effect on the expression of downstream genes in B. subtilis.

Still, there was a residual constitutive $\beta$-galactosidase activity in GM687 and GM688, which could have been due to leakage through the cat terminator, or to other elements, e.g. a promoter, in the part of the transposon located downstream of the SalI site. Deletions in this region led to reduced levels of $\beta$-galactosidase activity, and the effect of these deletions was correlated with their extent, contrary to what might be expected for the deletion of a promoter. Alternatively, the effect of this region could be to stabilize messenger RNA transcripts initiated upstream and extending through sac $Y$ (Tanaka \& Kawata, 1986), or to enhance the activity of a promoter for $\operatorname{sac} Y$ located at the very end of $\operatorname{Tn} 917$ or even downstream, in B. subtilis sequences (Reynolds et al., 1981).

Although our experiments did not allow us to localize precisely an activating sequence, nor to be certain about the involvement of one or several promoter(s), it is clear that several elements internal to the transposon are involved in the stimulation of $\operatorname{sac} Y$ transcription. This observation illustrates a limitation of transpositional mutagenesis as a tool for investigating the control of gene expression. The work presented here suggests a two-step strategy in order to distinguish between the effects of transposon insertions. In the first place, the phenotype conferred by a $\operatorname{Tn} 917^{\prime}::$ 'pTV21 $\Delta 2$ insertion should be different from that of the transposon alone. This difference could be due either to a phenomenon analogous to the one presented in this paper or to a polar effect of the cat gene (Vandeyar et al., 1986). Secondly, the use of plasmids of the pIC41 type, which lead to the insertion of a cat gene without affecting the promoter activity of the transposon (Fig. 3), allows these two possibilities to be discriminated easily.

\section{References}

Aymerich, S. \& Steinmetz, M. (1987). Cloning and preliminary characterization of the sacS locus from Bacillus subtilis which controls the regulation of the exoenzyme levansucrase. Molecular and General Genetics 208, 114-120.

Aymerich, S., Gonzy-Treboul, G. \& Steinmetz, M. (1986). 5'Noncoding region $\operatorname{sac} R$ is the target of all identified regulation affecting the levansucrase gene in Bacillus subtilis. Journal of Bacteriology 166, 993-998.

Berg, D. E. \& Howe, M. M. (editors) (1989). Mobile DNA. Washington, DC: American Society for Microbiology.

Ciampi, M. S., Schmid, M. B. \& Roth, J. R. (1982). Transposon Tn 10 provides a promoter for transcription of adjacent genes. Proceedings of the National Academy of Sciences of the United States of America 79, 5016-5020.

Crutz, A. M., Steinmetz, M., Aymerich, S., Richter, R. \& Le CoQ, D. (1990). Induction of levansucrase in Bacillus subtilis: an antitermination mechanism negatively controlled by the phosphotransferase system. Journal of Bacteriology 172, $1043-1050$.

Galas, D. J. \& ChandLER, M. (1989). Bacterial insertion sequences. In Mobile DNA, pp. 109-162. Edited by D. E. Berg \& M. M. Howe. Washington DC: American Society for Microbiology.

Henner, D. J., Yang, M., Band, L., Shimotsu, H., Ruppen, M. \& FERRARI, E. (1987). Genes of Bacillus subtilis that regulate the expression of degradative enzymes. In Genetics of Industrial Microorganisms (Proceedings of the Fifth International Symposium on the Genetics of Industrial Microorganisms), pp. 81-90. Edited by M. Alacevic, D. Hranueli \& Z. Toman. Karlovac: Ognjen Prica Printing Works.

Lepesant, J. A., Kunst, F., Pascal, M., Lepesant-Kejzlarova, J., SteinmeTz, M. \& DEDONDER, R. (1976). Specific and pleiotropic regulatory mechanisms in the sucrose system of $B$. subtilis 168 . In Microbiology 1976, pp. 58-69. Edited by D. Schlessinger. Washington DC: American Society for Microbiology.

MilleR, J. (1972). Experiments in Molecular Genetics. Cold Spring Harbor, NY: Cold Spring Harbor Laboratory.

MurPhy, E. (1989). Transposable elements in Gram-positive bacteria. In Mobile DNA, pp. 269-288. Edited by D. E. Berg \& M. M. Howe. Washington DC: American Society for Microbiology. 
Perego, M., Spiegelman, G. B. \& Hoch, J. A. (1988). Structure of the gene for the transition state regulator, $a b r B$ : regulator synthesis is controlled by the spoOA sporulating gene in Bacillus subtilis. Molecular Microbiology 2, 689-699.

Perkins, J. B. \& Youngman, P. J. (1984). A physical and functional analysis of $\operatorname{Tn} 917$, a Streptococcus transposon in the $\operatorname{Tn} 3$ family that functions in Bacillus. Plasmid 12, 119-138.

REIF, H. J. \& SAEDLER, H. (1975). IS1 is involved in deletion formation in the gal region of Escherichia coli K-12. Molecular and General Genetics 137, 17-18.

ReYNolds, A. E., Felton, J. \& WRIGHT, A. (1981). Insertion of DNA activates the cryptic bgl operon in $E$. coli $\mathrm{K}-12$. Nature, London 293, 625-629.

ShaW, J. H. \& Clewell, D. B. (1985). Complete nucleotide sequence of macrolide-lincosamide-streptogramin B-resistance transposon Tn 917 in Streptococcus faecalis. Journal of Bacteriology 164, 782-796.

Steinmetz, M., Aymerich, S., Le CoQ, D. \& Gonzy-Treboul, G. (1988). Levansucrase induction by sucrose in Bacillus subtilis involves an antiterminator. Homology with the Escherichia coli bgl operon. In Genetics and Biotechnology of Bacilli, vol 2, pp. 11-16. Edited by A. T. Ganesan \& J. A. Hoch. New York \& London: Academic Press.

TANAKA, T. \& KaWATA, M. (1986). Enhanced gene expression in Bacillus subtilis by Escherichia coli insertion sequences, IS5 and IS1.
In Bacillus Molecular Genetics and Biotechnology Applications, pp 467-477. Edited by A. T. Ganesan \& J. A. Hoch. New York \& London: Academic Press.

Vandeyar, M. A., Mackey, C. J., Lipsky, R. H. \& ZAHLeR, S. A. (1986). The ilvBC-leu operon of Bacillus subtilis. In Bacillus Molecular Genetics and Biotechnology Applications, pp. 295-305. Edited by A. T. Ganesan \& J. A. Hoch. New York \& London: Academic Press.

Youngman, P. (1987). Plasmid vectors for recovering and exploiting Tn917 transpositions in Bacillus and other Gram-positive bacteria. In Plasmids: a Practical Approach, pp. 79-103. Edited by K. Hardy. Oxford: IRL Press.

Youngman, P., Zuber, P., Perkins, J. B., Sandman, K., Igo, M. \& LosicK, R. (1985). New ways to study developmental genes in sporeforming bacteria. Science 228, 285-290.

Zukowski, M., Miller, L., Cogswell, P. \& Chen, K. (1988). An inducible expression system based on sucrose metabolism genes of Bacillus subtilis. In Genetics and Biotechnology of Bacilli, vol. 2, pp. 17-22. Edited by A. T. Ganesan \& J. A. Hoch. New York \& London: Academic Press.

Zukowski, M., Miller, L., Cogswell, P. \& Chen, K., Aymerich, S. \& StEINMETZ, J. (1990). Nucleotide sequence of the sacS locus of Bacillus subtilis reveals the presence of two regulatory genes. Gene 90 , 153-155. 